\section{Privatization makes progress}

London

THE two new British electricity generating companies, which will take over from the Central Electricity Generating Board (CEGB) when the industry is privatized, were launched last week. Lord Marshall, chairman of National Power, the larger of the two companies, said they relished the challenges of free market and that it was "wonderful" to move away from government control.

National Power will take over the lion's share of CEGB assets in preparation for its flotation, including responsibility for Britain's nuclear power stations. PowerGen, the smaller company chaired by Robert Malpas, which was formed to create competition, will be responsible for 26 per cent of the electricity supply. A third company, the National Grid Company, will run the transmission network. This will be a multi-million pound concern owned jointly by 12 distribution companies.

Many questions remain to be answered about the timing of the $£ 12,000-£ 13,000$ million sell-off and the future of nuclear energy. Britain's ageing Magnox reactors have been withdrawn from the sale but National Power will still inherit 46 power stations, including five nuclear advanced gas-cooled reactors (AGRs), from the CEGB. Lord Marshall dismissed the suggestion that the AGRs would also be hived off and said the problems and costs of decommissioning them are "negligible" compared with Magnox. An intense dialogue continues, however, between the government and National Power about possible changes in future safety regulations. National Power maintains that it cannot be responsible for changes in regulations such as more rigorous safety procedures. The government has offered $£ 1,000$ million to pay for "unforeseen nuclear costs" and is to put an increased sum of $£ 2,500$ million before parliament this autumn to sweeten the nuclear pill.

The flotation timetable is in disarray

\section{Rain-forest canopy remains elusive}

\section{São Paulo}

A NOVEL attempt to explore the upper canopy of the Amazon forest with a 'raft' suspended from a hot-air balloon was brought to a sudden halt last week when ten members of the French expediton were expelled from Brazil. The French group, headed by botanist Francis Hallé of the University of Montpellier II, had begun their activities without formal approval from the Brazilian government.

After a long wait for official approval of the project (see Nature 339, 569; 22 June 1989), Hallé and his colleagues arrived in Brazil with only tourist visas. They then test-flew their 'flying raft' near Manaus, in the state of Amazonas, without permission, angering the Ministry of Aeronautics.

Approval had been granted for the scientific part of the expedition from the Special Secretary for Science and Technology and the National Council for Scientific and Technological Development. But under Brazilian law, final approval could be granted only after study of the expedition proposals by the military.

The technicians were rash to set up the dirigible without waiting for final approval, admitted Gérard Xavier Kuhn, science and technology attaché at the French Embassy in Brasilia. Although Brazil's Ministry of Foreign Affairs was trying to play down the affair last week, the researchers will have to wait outside the country for approval for the expedition and for the proper visas.

\section{... and there's no help from Washington}

\section{Washington}

IN the United States, another novel project to reach the largely unexplored canopy of the tropical rain forest has ground to a temporary halt, but for a more conventional reason - the US Congress did not provide funds for it in the 1990 budget. Alan P. Smith, a scientist at the Smithsonian Institution, proposes to use a tall crane to reach the canopy. The crane could be set up even in inaccessible forest sites using a helicopter and, if required, moved from place to place. Precise and repeated access could be had to any point in the canopy within an 80-metre radius through the use of a manned gondola lowered from the crane.

Smith, who hopes to use the crane at the Smithsonian's research sites in Panama, says that the lack of such equipment means that carrying out research on the canopy is "like trying to do marine biology without a scuba system". Aerial ropeways have been constructed at several rain-forest sites but give easy access only to large branches, not to the branch tips where the flowers are, and where photosynthesis takes place.

A drawing of the crane, set in the midst of rain forest, appears in an exhibition at the Smithsonian which opened last week to celebrate the institution's tropical research and the completion of new research centre in Panama. But the crane itself, which requires an expenditure of $\$ 300,000$ plus construction costs, will have to wait until Congress is in a more generous mood.

Alun Anderson following the decision to remove the 26 Magnox reactors from the sale because of the potentially crippling costs of decommissioning them by 2002 . The two companies were to be sold separately in autumn 1990 and spring 1991 but now a six-month delay may result in a joint flotation shortly before the next election.

At a press conference in London, Andy Roe, National Power's information officer. said they were still committed to the introduction of pressurized water reactors (PWRs). The only problems lay in the immense capital expenditure and the need for a guaranteed market. It is essential for the National Power and the generation boards to draw up contracts to reduce the risks of building PWRs. He added that the PWRs were needed for National Power to reach the required production level of non-fossil fuel laid out in the privatization bill. He also said the obligatory $600 \mathrm{MW}$ of renewable fuel would be produced by the wind farm in Capel Cynon, South Wales.

$\mathrm{Mr}$ John Collier, chairman of the UK Atomic Energy Authority, said the nuclear industry would suffer from the government privatization programme. $\mathrm{He}$ said it was "unfortunate" that the government would be cutting research into fast reactors from $£ 50$ million to $£ 10$ million and would end support for the prototype fast reactor at Dounreay by 1994 . In the authority's annual report, he also said the drop in funding for nuclear fusion was "very serious".

Ben Webb

\section{Monkey dispute}

\section{Paris}

WhILE members of the French anti-vivisection group, Arche de Noé, face charges of theft, the 28 macaque monkeys stolen from a Lyons laboratory of the French national institute of health and medical research (INSERM) in May have still not been handed back to their owners (see Nature 339, 648; 1989). On Monday, INSERM's lawyer called for new charges of cruelty to be brought against the accused. Meanwhile a court of appeal was due last Tuesday, 22 August, to decide the fate of the monkeys, following the expiry of a custody order.

INSERM claims that identification tattoos removed by Arche de Noé involved the animals in unnecessary suffering and says that the wounds had not healed well. Arche de Noé has denied this. In a communique the group says that "the monkeys were operated on by a team of three veterinarians, under general anesthetic and in conditions of perfect asepsia".

"It is inconceivable", says the communiqué, "that our colleagues who risk their freedom for animals should be accused of acts of cruelty against these same animals."

Peter Coles 